This work was supported by U.S. Public Health Service research grants $A I-05785$ and $H E-07495$ from the National Institute of Allergy and Infectious Diseases and the National Heart Institute, and in part by the Michigan Leukemia Foundation of Michigan.

M. D. Poulik J. Shuster

Child Research Center of Michigan,

Detroit 2, and

Department of Pediatrics,

Wayne State University School of Medicine, Detroit 7, Michigan.

${ }^{1}$ Tisellus, A., and Friksson-Quensel, I. B., Biochem. J., 33, 1752 (1939). 2 Porter, R. R., Biochem. J., 73, 719 (1959).

${ }^{3}$ Schlamowitz, M., Peterson, U. L., and Wissler, F. C., Arch. Biochem. Biophys., 92, 58 (1961).

${ }^{4}$ Poulik, M. D., Nature, 198, 752 (1963)

"Migita, S., and Putnam, F. W., J. Exp. Med., 117, 81 (1963),

'Thorpe, N. O., Mackenzie, M. R., and Deutsch, II. F., Acta Chimica Scand. 17, $154(1963)$.

' Kunkel, H. G., in Methods of Biochemical Analysis, 1, 141 (1954).

s Poulik, M. D., Nature, 180, 1477 (1957).

' Schrohenloher, R. E., Arch. Biochim. and Biophys., 101, 456 (1963).

${ }^{10}$ Takatsuki, K., and Osserman, E. F., Science, 145, 499 (1964).

${ }^{11}$ Grey, H. M., and Kunkel, H. G., J. Exp. Med., 120, 253 (1964).

13 'Terry, W. D., and Fahey, J. L., Fed. Proc., 23, 454 (1964). ${ }^{13}$ Kunkel, H. G., Allen, J. C., Grey, H. M., Martensson, L., and Grubb, R. A.,

\section{Reduction and Re-oxidation of the Disulphide Bonds of Soy Bean Trypsin Inhibitor}

Several examples have recently been reported of the partial or complete recovery of the native conformation and the biological activity of a protein following the reduction of all disulphide bridges under strongly denaturing conditions, such as $8 \mathrm{M}$ urea or $5 \mathrm{M}$ guanidine hydrochloride. The examples include insulin ${ }^{1}$, ribonuclease $^{2}$, lysozyme ${ }^{3}$, and pepsinogen ${ }^{4}$. In each case the recovery was induced by removing the reducing agent and denaturing solvent and allowing the disulphide bridges to re-form spontaneously through re-oxidation of sulphydryl groups by atmospheric oxygen.

Since the loss of the native molecular organization is generally very extensive for reduced, denatured proteins, these results are of importance as a direct test of the hypothesis that the overall configuration of proteins is primarily determined by their amino-acid sequence ${ }^{5}$.

Investigations in this laboratory have recently demonstrated that soy bean trypsin inhibitor is likewise capable of a major degree of recovery of its native structure after treatment of this kind. The organized structure of this protein has been shown to be rather refractory to the action of $9 \mathrm{M}$ urea at neutral $p \mathrm{H}$ and $25^{\circ} \mathrm{C}^{6}$. Exposure to alkaline $p H$ or elevated temperatures in this solvent results in a time-dependent transition to a molecular state which is much more loosely organized, as judged by changes in intrinsic viscosity, optical rotation, and rotational relaxation time ${ }^{6}$.

Soy bean trypsin inhibitor (STI) consists of a single polypeptide chain of molecular weight 21,000 which is cross-linked by 2 disulphide bridges? ${ }^{7}$ Treatment of 1 per cent STI (Worthington) solutions in $9 \mathrm{M}$ urea, 5 per cent $\beta$-mercaptoethanol for $20-30 \mathrm{~min}$ at $57^{\circ}$ resulted in quantitative reduction of cystine groups to cysteine, as determined by titration with $p$-chloromercuribenzoate ${ }^{8}$. The product of the combined reduction and denaturation under these conditions exists in an advanced state of molecular disorganization, as indicated by the high value of intrinsic viscosity $(21.2$ $\mathrm{ml} . \mathrm{g}^{-1}$ ), and low value of rotational relaxation time $\left(p_{h}^{25}=1 \cdot 6 \times 10^{-9}\right)$, as determined by fluorescence polarization?. However the non-vanishing value of the latter parameter suggests that some structural restraints may survive under this condition.
Removal of urea and mercaptoethanol by passage through a 'Sephadex G-25' column, eluting with $0 \cdot 1$ M NaOAc, $p \mathbf{H} 5 \cdot 6$, yields the reduced protein in water. This material has little or no inhibiting capacity $(<2$ per cent of native) for trypsin, as determined by assay with the substrate tosyl arginine methyl ester at $p \mathrm{H} 7 \cdot 5$, $25^{\circ}$ (ref. 10).

Air oxidation of a $0 \cdot 1-0.3 \mathrm{~g} / \mathrm{l}$. solution in $0.1 \mathrm{M}$ phosphate, $p \mathrm{H} 8.0$ for $48 \mathrm{~h}$ at $25^{\circ}$ results in quantitative reformation of disulphide bridges to yield a re-oxidized product with 30-40 per cent of the trypsin-inhibiting capacity of the original (Table 1). Ultracentrifugal examination of the product, after re-concentration by pervaporation, shows two components of sedimentation coefficient 4.7 and 2.2 ( 1 per cent STI in $0.1 \mathrm{M}$ potassium chloride, $0.01 \mathrm{M}$ phosphate, $p \mathbf{H} 7$ ). The value for the latter component is close to that for native inhibitor.

Table 1. Properties of Reoxidized STI Preparations

$\begin{array}{cccc}\text { Preparation } & \begin{array}{c}\text { Per cent } \\ \text { reduction }\end{array} & \begin{array}{c}\text { Per cent } \\ \text { activity } \\ \text { re-oxidized } \\ \text { material }\end{array} & \begin{array}{c}\text { Per cent } \\ \text { activity } \\ \text { monomeric } \\ \text { fraction* }\end{array} \\ \text { STI-R-1 } & 90 & 42 & - \\ \text { STI-R-3 } & 100 & 43 & 81 \\ \text { STI-R-4 } & 100 & 38 & 85 \\ \text { STI-R-5 } & 100 & & 100 \\ \text { STI- } R-6 & 93 & & 61\end{array}$

Reduction was carried out in $9 \mathrm{M}$ urea, $0 \cdot 1 \mathrm{M}$ phosphate, $p \mathrm{H} 7 \cdot 7$, for $15-20$ $\min$ at $58^{\circ}$. Re-oxidation was carried out in $0.1 \mathrm{M}$ phosphate, $p \mathbf{H} 8.0$ for $48 \mathrm{~h}$ at $25^{\circ}$. The concentration of STI was $0 \cdot 1$ to $0 \cdot 3 \mathrm{~g} / 1$.

* Obtained by 'Sephadex $G-100$ ' fractionation.

The two components could be separated by fractionation on a 'Sephadex $G-100$ ' column. The elution pattern of re-oxidized STI showed two major components and sometimes a minor ( $<10$ per cent) trailing component. The leading component ( $F$ I) and the second elution peak ( $F$ II) had sedimentation coefficients of 4.7 and $2 \cdot 2$ respectively ( 1 per cent STI in $0 \cdot 1 \mathrm{M}$ potassium. chloride, $0 \cdot 01 \mathrm{M}$ phosphate, $p \mathrm{H} 7$ ).

Almost all the inhibitory activity of the re-oxidized material was present in fraction $F$ II, the specific activity of which was $80-100$ per cent of the native protein. There was some indication of a slight ( $<10$ per cent) activity in $F \mathrm{I}$, but the possibility of contamination with $F$ II has not been rigorously excluded.

The monomeric fraction ( $F$ II) probably closely resembles the native material in structure, in view of its sedimentation properties and biological activity. It would, however, be premature to equate it with the original in all structural aspects. It is clear that the process, competitive with re-formation of the native molecule, involves aggregation, possibly through formation of intermolecular cystine bridges.

It may be concluded that soy bean trypsin inhibitor may be added to the list of proteins which are capable of spontaneous re-formation of a conformation resembling the native after an extensive loss of structure.

\section{R. F. Steindiz}

Biological Macromolecules Branch, Physical Biochemistry Division, Naval Medical Research Institute, National Naval Medical Center, Bethesda, Maryland.

1 Yu-Cang, D., Yu-Shang, Z., Zi-Nian, E., and Chen-Iu, T., Scienta Sinica, $10,84(1961)$

${ }^{2}$ Epstein, C., Goldberger, R., Young, M., and Anfinsen, C., Arch. Biochem. Biophys., Suppl. 1, 223 (1962).

${ }^{3}$ White, F., Fed. Proc., 21, 233 (1962).

${ }^{4}$ Fratelli, V., Steiner, R., Millar, D., and Edelhoch, H., Nature, 199, 1186 (1963).

'Anfinson, C., Brookhaven Symp, Biol, No 15, 184 (1962).

- Edelhoch, H., and Steiner, R., J. Biol. Chem., 288, 931 (1963).

"Wu, Y., and Scheraga, H., Bioch., 1, 905 (1962).

s Boyer, P., J. Amer. Chem. Soc., 76, 4331 (1954)

${ }^{B}$ Steiner, R., and Edelhoch, H., Chem. Rev., 62, 457 (1962).

${ }^{10}$ Hummel, B., Canad. J. Biochem. Physiol., 87, 1393 (1959). 